\section{Over Grænsen. Forbindelser mellem dansk og tysk musikliv 1760-1914}

afforstebibliotekar Niels Krabbe, Det Kongelige Bibliotek

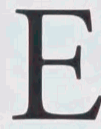

n udstilling med ovenstående titel, der fra 3. feburar 2007 vises i Søjlesalen på Det Kongelige Bibliotek, er en lettere revideret version af en udstilling, som biblioteket præsenterede i Göttingen i 2004 under titlen Wahlverwandschaften. Zwei Jahrhunderte musikalischer Wechselwirkungen zwischen Dänemark und Deutschland.

Sproglige og kulturelle forbindelser mellem tysk og dansk kulturområde har været fremtrædende så langt tilbage som kulturhistorien rækker. Talrige danske kunstnere er rejst til Tyskland på dannelsesrejser og vendt hjem med varige og stærke indtryk, ligesom tyske kunstnere i kortere eller længere tid har slået sig ned i Danmark og derved bidraget til en styrkelse af dansk kultur, men også til internationalisering af den nationale kultur.

Det gælder i høj grad også inden for musikken, hvor komponister og musikere nord og syd for den dansk-tyske grænse gensidigt har påvirket og inspireret hinanden . Naturligvis er påvirkningen fortrinsvis gået fra syd mod nord, og dansk musik og musikliv har gennem tiderne nydt godt af de impulser der kom sydfra og som var med til at holde den provinsialisme i ave, som naturligt har været en følge af Danmarks størrelse og beliggenhed.

Ikke mindst perioden 1760 1914, som udstillingen Over Gransen dækker, var rig på sådanne forbindelser mellem de to kulturer. Det begyndte med, at en række markante tyske komponister som J.E. Hartmann, J.A. Scheibe, F.L.Ae. Kunzen og J.A.P. Schulz opholdt sig i Danmark og alle bidrog til etableringen af det lidt vage begreb "den danske tone", og gik frem til at Carl Nielsen, der med sit angiveligt særlige danske tonesprog, forsøgte at etablere sig som navn i Tyskland.

Med enkelte undtagelser - specielt i årene efter $1864 \mathrm{og}$ i perioden 1933 1945 - har den tyske indflydelse og den tyske inspiration i Danmark været af helt afgørende betydning. Ikke sådan at forstå at den bare ureflekteret er blevet accepteret. Men det har netop været styrken i forholdet: indflydelsen er i perioder blevet anfægtet, udfordret, diskuteret etc. - og bliver det

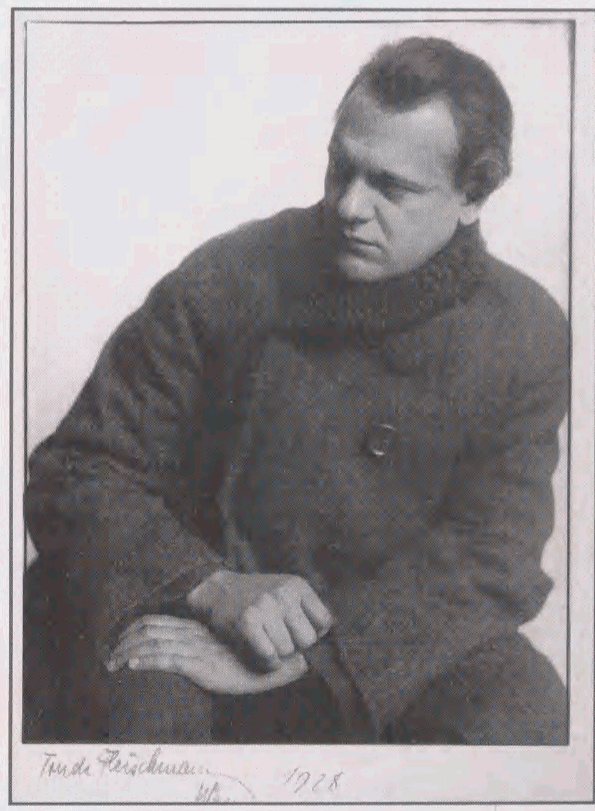

Den danske komponist Paul van Klenau (18831943), som i efter studier $i$ Kobehavn i en lang àrrakke virkede $i$ Tyskland som komponist og fejret dirigent. Som det fremgår af Klenaus påskrift var dette foto en jule-og fodselsdagshilsen til komponistens mor 
den dag i dag - men ligegyldig har den sjældent været. Hermed er også sagt, at hvor nødig vi som "den lille" i dette forhold end vil indrømme det, så er indflydelsen i alt væsentligt gået fra syd mod nord, og kun i få enkeltstående tilfælde den modsatte vej, fra nord mod syd. Det er og bliver en relation mellem "den store" og "den lille", med alt hvad det indebærer. Eller sagt mere positivt: når regnskabet skal gøres op, er det ubetinget Danmark der har haft størst gavn af den musikkulturelle udveksling mellem de to lande.

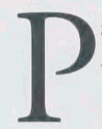

å et enkelt punkt kan denne danske version af udstillingen præsentere nyt materiale i forhold til Göttingen-ud- stillingen fra 2004. Det drejer sig om eksempler fra den meget store Paul van Klenau samling, som i 2001 dukkede op i Wien, og som det i 2005 lykkedes Det Kongelige Bibliotek at erhverve - ikke mindst i kraft af en særbevilling fra Kulturministeriet.

Den danske komponist Paul van Klenau virkede i de første årtier af det 20. århundrede i Tyskland og Østrig og havde her et stort navn både som komponist, som skribent og som dirigent, hvorimod han i sit hjemland Danmark både i sin egen levetid og i eftertiden har været noget marginaliseret. Hele hans tonesprog med dets stærke præg af senromantik og ekspressionisme var helt fremmedartet i forhold til den samtidige musik i Danmark. I de senere år har man

Registrant -udarbejdet af Paul van Klenaus anden hustru Margrethe Klimt - over indholdet af den store Klenau samling, som i 2001 dukkede op $i$ Wien, og som i 2006 kom til Det Kongelige Bibliotek. Samlingen indeholder en rakke hidtil ukendte verker af Klenau i autograf, ligesom den indeholder manuskripter til knap 80 foredrag og artikler af den danske komponist.

Som helhed vil samlingen formentlig give mulighed for en radikal omvurdering af Paul van Klenau.

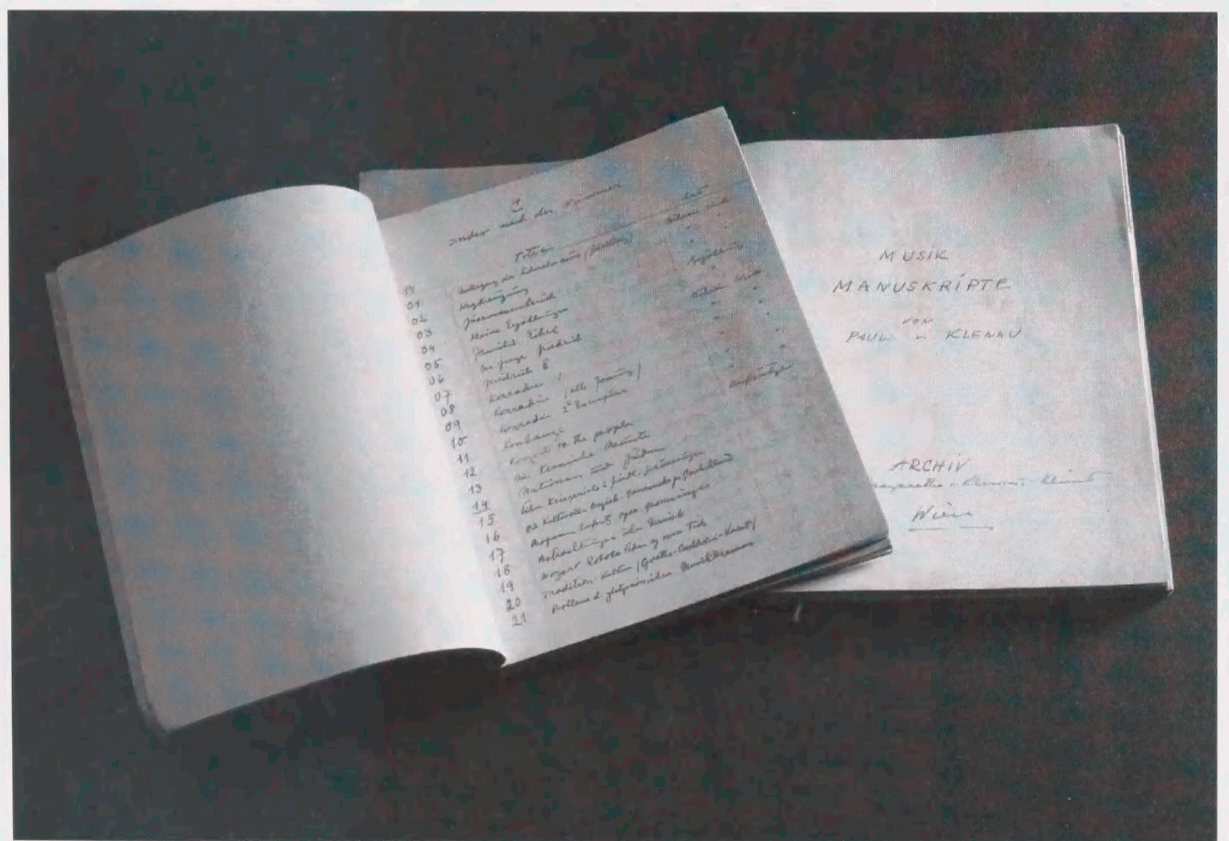


mærket en forøget interesse for Klenaus musik, og den omtalte samling af autografe partiturer (herunder hidtil ukendte værker), arkivalier, foredragsmanuskripter m.m. giver mulighed for en nyvurdering af denne meget produktive komponist.

Samlingen har ligget hengemt $\mathrm{i}$ et sommerhus i Tyrol og en herskabslejlighed på sjette sal i en mindre gade i Wiens centrum i mere end 50 år siden Klenaus død i 1946. Det er tydeligt, at den så at sige har "ventet på bedre tider", helt håndgribeligt derved at Klenaus anden hustru, billedhuggeren og maleren Margrethe Klimt, omhyg- geligt har ordnet samlingen og minutiøst gennemregistreret den i to stilehæfter, som for forskerne vil danne en nyttig indgang til den omfattende samling.

Blandt udstillingens øvrige "highlights" skal nævnes en side fra et af Beethovens mange såkaldte „konversationshæfter" (hæfter hvor Beethovens omgangskreds hastigt kunne indskrive spørgsmål og bemærkninger til den døve komponist), som vidner om den danske komponist Kuhlaus og Beethovens muntre samvær efter en bedre frokost engang i september 1825. 